\title{
The Timing of Presidential Scandals: The Role of Economics, Divided Government and the Media
}

\author{
Thomas E. Sowers II, James P. Nelson \\ Department of Political Science, Lamar University, Beaumont, TX, USA \\ Email: Thomas.sowers@lamar.edu
}

Received 24 November 2015; accepted 26 January 2016; published 29 January 2016

Copyright (C) 2016 by authors and Scientific Research Publishing Inc.

This work is licensed under the Creative Commons Attribution International License (CC BY). http://creativecommons.org/licenses/by/4.0/

\section{c) (i) Open Access}

\begin{abstract}
The political consequences of presidential scandals have received a great deal of attention in both the media and scholarly work. The role of the media and the impact of presidential approval are some the most common topics. In this study, we develop models that predict the type of political environment that is most likely to produce a scandal. The findings link the occurrence of presidential scandals with the performance of the economy and the presence of divided government. A strong economy creates favorable conditions for scandals. Divided government is shown to be an almost necessary condition for a presidential scandal to occur.
\end{abstract}

\section{Keywords}

\section{Presidential Scandal, Divided Government}

\section{Introduction}

Scandals, especially presidential scandals, often retain the attention of the American public with intensity unparalleled by most other types of news coverage. Scandals are a very common topic of discussion among news outlets and they are a topic that can become even more newsworthy when the wrongdoing of a president is involved. Scandals have become such a strong influence on the way that Americans view their political leaders that it has even been surmised that scandals are the primary means of conflict within American politics (Williams, 2000). The importance of presidential scandals within American culture and the political process has been established in a number of scholarly works. Some studies have focused on the impact of particular scandals such as Renshon( 2002a, 2002b). Other studies have looked at the role of the media by looking at the feeding frenzies that often surround scandals (Sabato, 1991; Maurer, 1999). Finally, some studies have focused on the impact 
that scandals have on presidential approval (Kagay, 1999; Fackler \& Lin, 1995), which will be the starting point for our analysis. Presidential approval is the percentage of people that agree with the job that the President is doing. Our analysis then moves beyond this point and attempts to predict the occurrence of scandals. We argue that there is a systematic component to the timing of scandals. Scandals are more likely to occur when there is a strong economy and there is divided government. Because of this, we can in fact explain and predict scandals rather than treating them as random events. We believe that there are always events that can be perceived as scandalous depending on the perspective. Political spin can change something relatively benign or minor into a scandal. We attempt to explain why some of these events "get legs" in the media and with the public while others are ignored.

\section{The Relationship between the Presidency, Scandals, and the Economy}

The most obvious effect of a presidential scandal would be a negative impact on presidential approval. ${ }^{1}$ One of the many factors influencing presidential approval ratings is the perceived integrity of the president. Greene (2001) illustrates a president's personal integrity can play an important role in how the president is evaluated. A scandal brings the integrity of a president into question. The negative media attention that is associated with presidential scandals should manifest itself in lower overall approval ratings. The most notable exception is the case of President Clinton. Despite the accusations against the Clintons, the general public did not see Whitewater as a scandalous event (Williams, 2000). His approval ratings were also supported by a strong economy throughout most of his term. The strong economy and the public indifference to the initial scandal allowed people to easily separate his job performance and his personal integrity, which is very rare.

The media plays a critical role in the development of scandals. Scandals make up a very significant portion of the media's coverage of politics. It has been proposed that scandals have become such a strong force in politics that issues have fallen by the wayside in favor of scandals as the main source of political contention. The media's behavior during a scandal has been compared to a feeding frenzy among sharks by Sabato (1991) and more recently by Maurer (1999); although Maurer found some evidence that did not support the feeding frenzy idea. ${ }^{2}$ This prevalence of political scandals has figured into analyses of the 2000 presidential election, with the argument being made that George W. Bush's ascension to the office of the presidency was facilitated by Clinton's scandalous behavior (Renshon, 2002b).

Beyond scandals, presidential approval ratings are influenced by many factors, the most important of which is the performance of the economy. A strong economy, both actual and perceived, has a positive effect on presidential approval. Although the president's job performance is often evaluated based upon unrealistic standards that do not take into account the limitations of his legal authority to control the economy (Pfiffner, 1994), economic issues play a pivotal role in presidential approval ratings. In a recent example Nadeau, Niemi, Fan, \& Amato (1999) examine how news coverage of the economy impacts presidential approval.

The literature on the relationship between the presidency and economics is divided into the retrospective approach, in which people's view of the president are based on how the economy has performed, and the prospective approach, in which people's opinions are based on how they expect the economy to perform in the future. Typically these models attempt to predict either vote choice or approval ratings. A good example of this can be found in Norpoth (1996) in which the effect of the public's expectations of the overall economy's future performance on presidential approval was Contrasted against the effect of previous economic conditions on the public's assessment of their president. Norpoth found that presidential approval was heavily influenced by a retrospective approach (Norpoth, 1996).

The prospective approach also has a number of advocates, including Abramowitz (1985), Lockerbie (1992) and to some extent Lanoue (1994). In Abramowitz's (1985) research, predictions of future economic conditions were found to have significantly impacted people's assessments of President Reagan in 1982. Lanoue (1994) looks at the 1984 and 1988 presidential elections and finds some support for both the retrospective and the prospective approach.

The last major systematic factor impacting presidential approval is international conflict. Presidential approval is sensitive to warfare. While most people perceive war to be necessary in some cases, they often become less

\footnotetext{
${ }^{1}$ This never really materialized in the case of Clinton. Greene points out that Clinton's high job approval rating during the Lewisnky scandal was a result of surveys with separate questions regarding job approval and personal values.

${ }^{2}$ In Maurer examination of the coverage of the Paula Jones and Gennifer Flowers cases, he found that Sabato's assertions regarding the behavior of the media did not always materialize.
} 
disposed toward believing that a war is worthwhile when the number of their fellow citizens dying on the battlefield escalates without significant progress in their efforts to defeat the enemy. Numerous studies (i.e. Parker, 1995) have explored the impact that wars can have on public opinion, particularly focusing on the rally effect that occurs early on in a conflict. The rally effect is a temporary phenomenon with the approval benefits of the conflict dissipating over time. This relationship between international conflict and presidential approval serves as the foundation for diversionary theory, which is beyond the scope of this research.

\section{Scandals}

Throughout the course of American history many presidents have had both public and private aspects of their lives appear to be scandalous. Accusations of sexual improprieties date back to George Washington (Schultz, 2000) and allegations about abuse of power, such as the Teapot Dome scandal have been standard in presidential politics. In order to better study scandal we have developed a concise definition of a presidential scandal for use in this analysis. For the purposes of this analysis, a presidential scandal is defined as any actual or perceived misconduct directly involving the president and prompting a congressional and/or independent counsel investigation. This definition forces us to focus on incidents of which nearly all of the American people were aware because it is impossible for an event to be scandalous if few people know about it. Also, the fact that the president is the subject of a high-level investigation in each of our selected cases indicates that a significant portion of the population not only knew about his alleged misconduct, but also felt that it was inappropriate. The assertion by others that a president's conduct was inappropriate is what clearly delineates a scandal, because without a public outcry many types of scandalous behavior could be classified as private indiscretions. The scandals that meet the criteria are: Watergate, the Iran-Contra, and President Clinton's impeachment scandals. These cases were the only scandals from 1948 to 2000 that included actual or perceived wrongdoing by a sitting president and prompted a congressional and/or independent counsel investigation (Schultz, 2000).

\subsection{Watergate}

In the early morning hours of June 17,1972 , five men were arrested for burglary inside the Democratic National Committee's headquarters, one of whom had been previously involved in the CIA's activities (Olson, 2003: pp. 44-45). Two days after the break-in, The Washington Post featured a story that asserted that James McCord, who had been directly involved in the break-in, was CREEP's (Committee for the Re-election of the President) security coordinator and had also served the Republican National Committee. Carl Bernstein and Bob Woodward reported on the burglary for The Washington Post and ceaselessly pursued more information in order to discern what had actually occurred. Shortly thereafter, efforts to conceal the administration's and CREEP's involvement were initiated by White House aides. They gave official investigators false information and made evidence unavailable.

After seven convictions in connection to the Watergate break-in, the Select Committee on Presidential Campaign Activities was instituted by the Senate (Schultz, 2000). Nixon had covertly taped the conversations he had held with others within the Oval Office. A subpoena was issued by the special prosecutor, asking that the tapes be handed over to him (Schultz, 2000). Nixon did not release the tapes and said that his actions were protected by executive privilege (Schultz, 2000). The debate over the tapes was eventually brought before the Supreme Court, which stated in an 8-0 ruling that Nixon was obligated to turn over all tapes that had been subpoenaed by the special prosecutor (Olson, 2003). The tapes later released on August 5 tied Nixon to the activities in question and served as incontrovertible evidence that the involvement of the administration in the break-in at Watergate had been concealed pursuant to Nixon's orders. Facing impending impeachment and a subsequent conviction, Richard M. Nixon voluntarily ceded the office of the presidency on August 9, 1974.

\subsection{Iran-Contra}

The Contras were a group of rebels opposed to the Sandinistas in Nicaragua. In compliance with President Reagan's directives, the Contras became the most important issue in US foreign policy in the western hemisphere by the end of 1981. President Reagan gave the CIA the authority to act in opposition to the Sandinistas through the support of paramilitary activity as well as political actions. False information was given to Congress by the president regarding this issue; President Reagan said that the money that he was attempting to obtain was going to be utilized to prevent arms trafficking in Central America. A law known as the Boland Amendment was later 
passed by Congress in December 1982 and prohibited the funding of activities opposed to the Sandinista government by both the Department of Defense and the CIA. Afterward, the Boland Amendment was modified by Congress in order to make it unlawful for an American intelligence agency to give the Contras any form of aid that could be used to kill.

Due to these provisions of the Boland Amendment, the White House opted to utilize the resources of the National Security Council (NSC) to achieve its aims in Central America. The NSC is not obligated to answer to anyone other than the president and is not required to inform Congress of its activities. Colonel Oliver North was chosen by the administration to coordinate the activities that pertained to the Contras. When the Americans began selling arms directly to Iran without going through a third party, Oliver North became responsible for orchestrating these operations. The profits made from selling arms to Iran were used by North to fund the Contras.

A C-123 cargo plane that was later discovered to be property of Southern Air Transport was blown out of the Nicaraguan sky on October 5, 1986 and contained supplies that were to be delivered to the Contras (Schultz, 2000). Southern Air Transport was a false company in Miami whose name was used to cover CIA activities. More than a month after the crash, on November 22, a memo was found in the files of the NSC by officials of the Department of Justice that showed that money made by selling weapons to Iran was utilized to assist the Contras financially.

A congressional investigation followed and Lawrence Walsh was appointed to the position of independent counsel in order to investigate the matter. In the subsequent congressional investigation, during hearings that could be viewed on television throughout the country, North claimed that he was given approval to act in the manner that he did by those at the top of the chain of command. In this case, because the NSC was involved, the person who was at the apex of the theoretical pyramid would have been President Reagan. Despite President Reagan's pivotal role in choosing to assist the Contras, it is still not known with any certainty whether he realized that the financial assistance that was given to the Contras was related to the sale of weapons to Iran.

\subsection{Whitewater/Monica Lewinsky}

The Clinton impeachment scandal was the result of the tying together of three different scandals. Webster Hubbell, an attorney who had been a partner at the same firm as Hillary Clinton, was indicted in the Whitewater scandal and pleaded guilty, but did little to assist in the investigation despite assurances of his cooperation (Schultz, 2000). Senior White House aides set up consulting jobs for Hubbell, and he received more than \$700,000 as compensation for them (Schultz, 2000; Quirk, 2000). The payment for these jobs became a subject of investigation when Kenneth Starr, the independent counsel for the Whitewater investigation, looked into the possibility that the previously-mentioned jobs and the subsequent payment were set up for Hubbell in order to keep him from talking to prosecutors. Hubbell did not report more than half of the funds he received and faced charges of tax evasion as a result. A retainer of $\$ 60,000$ had been secured for Hubbell by Vernon Jordan, which brought Jordan into Ken Starr's investigation. In an unrelated lawsuit, many people were subpoenaed by Paula Jones's attorneys in order to try to demonstrate Clinton's behavioral patterns; the individuals subpoenaed included Monica Lewinsky, among others.

Starr became aware of the affair between Clinton and Lewinsky and on January 7, 1998 Monica Lewinsky signed an affidavit that falsely asserted that she did not have an affair with the President. Starr investigated whether this fabrication was prompted by Vernon Jordan or President Clinton. Starr later set out to substantiate the claims that the president had prompted Lewinsky to sign the affidavit and that the deposition provided by Clinton in the Paula Jones lawsuit was not entirely truthful.

On September 9, 1998, Starr's highly-detailed report that had been intended to prove these assertions was delivered before the House of Representatives and he assured them that he had discovered some evidence that could warrant impeachment. On October 8, the House of Representatives decided to initiate an inquiry into the impeachment of the president. On November 19, hearings on the subject commenced. One month later, on December 19, two of the proposed articles of impeachment were approved by the House. These two articles accused Clinton of obstructing justice during his efforts to hide the affair he had engaged in with Monica Lewinsky and giving false testimony to a grand jury. January 7, 1999 marked the beginning of Clinton's trial in the Senate which was presided over by Chief Justice William Rehnquist (Schultz, 2000). Clinton was not convicted of either of the charges that were specified in the articles of impeachment (Schultz, 2000; Gerhardt, 2000).

Although these scandals are unique events in U.S. history we believe that there are systemic components that 
make the occurrence of scandals more likely. In order for a scandal to occur the media must report the behavior, the public must care about the behavior and other political actors must be willing to take action. We believe that there are environments in which this will be more likely to occur as well as environments that will stifle scandals from ever reaching the point of an investigation. In the next section we will explore how scandals interact with the political process.

\section{Modeling Presidential Approval and Scandal}

The first objective of this research project is to measure the impact that scandals have on presidential approval. Presidential approval is measured monthly using the Gallup Poll data. In months with multiple polls the polls were averaged. If no poll was available, a value was interpolated for that month. We use Prais-Winsten regression models to control for first order serial correlation. ${ }^{3}$ An Augmented Dickey Fuller statistic of -4.645 ( $p$. < 0.01 ) indicates that we can reject the hypothesis that there is a unit root (unit roots trend and do not vary around the series mean as in a random walk series), in the time series and therefore there is no need to difference the dependent variable. We expect scandals to have a negative effect on presidential approval. Scandals should adversely affect the public's view of the president's integrity which in turn should adversely impact his approval rating.

There are a number of important control variables that must be included in the model. The economy is critical when modeling presidential approval. We employ two measures in our analysis. The first measure we selected to gauge the state of the economy is the misery index, which is the sum of the rate of unemployment and the rate of inflation. The data that was used to calculate the misery index was obtained from the U.S. Bureau of Labor Statistics. The misery index is a strong determinant of the actual state of the economy because it combines two economic indicators that measure different aspects of the economy. The rate of inflation measures the decreasing value of the dollar, which decreases the purchasing power of American consumers, while the unemployment rate measures the percentage of the American workforce that is currently seeking employment. By combining these indicators of the state of the economy, the misery index helps us to discern more about the overall state of the U.S. economy than either of its component statistics could if they were employed as separate independent variables. The effect of the misery index on presidential approval has already been examined in the past. Brace \& Hinckley (1991) found that the misery index had a negative impact on presidential approval. In addition, many scholars have used unemployment and inflation separately to predict presidential approval.

The second measure of the economy that we employ in our analysis is the Consumer Sentiment Index (CSI). The CSI is compiled by the University of Michigan Consumer Center ${ }^{4}$, with quarterly data going back to 1960 . The CSI is the public's perception of the future state of the economy. The CSI is composed of many people's attitudes toward prospective economic conditions, which makes it an excellent indicator of whether people think that the future state of the US economy will be prosperous or unfavorable. The CSI provides a nice Contrast to the misery index, which is more concretely tied to the current economic conditions of the country. We will include the variables separately and together in models.

In addition to the constant impact of the economy there are also unique events that can influence presidential approval. International conflict can have a major impact on a president's approval ratings. To control for this, we include a variable for each major war involving the United States from 1948 to 2000. This includes the Korean War, the Vietnam War and the Gulf War. We tried two different specifications of the variable. The first specification captures the impact of the initiation of conflict, with a dummy variable coded as 1 in the month in which the war was initiated. The second measure captures the impact of the entire conflict, with a dummy variable coded as 1 for every period during the war. The initiation variable was only significant in the case of the Gulf War.

The last variable measures the honeymoon effect that occurs when a new president is elected. Presidents typically enjoy high approval rating when they come into office. We therefore need to control for this short-term boost at the beginning of the term. We code the honeymoon period as lasting for the first three months in office. We also ran a model that included dummy variables for each administration. The results of the two models were consistent with one another, so we opted for the more parsimonious model.

\footnotetext{
${ }^{3}$ See Beck (1991) for a discussion of time series issues associated with modeling presidential approval.

${ }^{4}$ http://www.sca.isr.umich.edu
} 


\section{Scandals}

There are two major problems in trying to predict presidential scandals. The first problem is that they have typically been treated as random events. We argue that although there may be a random component to scandals, there is also a systemic component that would allow us to develop a theory that explains the occurrence of scandals. We focus primarily on the impact of divided government and the economy as the major explanatory variables. The second problem in studying scandals is that scandals are rare events which can make it difficult to get significant leverage on the dependent variable. We believe that we are at a point that enough scandals have occurred that we can have significant success in developing a theory to explain and predict major presidential scandals.

Media coverage of a scandal is a necessary condition for a lasting scandal. Without media attention there are few political gains to be had from pursuing a scandal. Since the media is a highly competitive business we expect them to focus on issues that will keep the public's interest. This leads to our first expectation about the timing of scandals. Scandals will occur during times of economic prosperity. When the economy is performing poorly, daily consumers of news would want to know whether the state of the national economy is improving or getting worse. When the economy is performing well, people would be less concerned about the state of the economy and would be more likely to watch news broadcasts for entertainment purposes. With a strong economy, media outlets would have ample time to devote to scandalous behavior. The opposition party also has a greater incentive to focus on a political scandal during times of economic prosperity in an attempt to decay the high levels of support for the president that is typically associated with a strong economy. Because of these two factors we hypothesize that stronger economic indicators will increase the likelihood of scandals.

The second major factor that influences the timing of scandals is the presence of divided government. Sinclair (2000) shows that divided government has increased the competition between the branches of government and intensified partisan politics. Conley (2003) also looks at the impact of divided government on the legislative process. More closely related to scandals, Mayhew (1991) explores the impact of divided government on Congressional investigations of the executive branch. He finds an almost constant state of investigation by Congress regardless of divided government, with only the House being more likely to initiate investigations during periods of divided government. We believe that divided government is an almost necessary condition for these investigations to reach the point of scandal. During periods of divided government the investigations should be more likely to take the fervid pitch that is needed to create public attention.

In addition to the state of the economy and divided government, many other factors have an effect upon the timing of presidential scandals. Major international conflict should pull the public's attention away from the president's behavior and make them focus on the ongoing conflict. International conflict also produces the rally around the flag effect that would dampen a presidential scandal as the nation supports the president in times of crisis. This preference would give the media a disincentive to report on presidential scandals and a strong incentive to report on the progress of the war. For these reasons, we hypothesize that warfare will negatively affect the incidence of a presidential scandal. There are three major wars included in the time frame of the study. Korea and Vietnam are both included in the model. The Gulf War is dropped out because of the short time span and the perfect correlation with the absence of scandal, which supports our expectation. We used data from the Militarized Interstate Dispute dataset ${ }^{5}$ to determine the beginning and end of each conflict. We also include a control variable for the honeymoon period to allow time for the president to develop a record. It is almost impossible for a scandal to occur before the president has established himself in the office.

We employed two different logit models to discern the effect of economic conditions on the incidence of presidential scandals. Both models included a lag of the presidential approval rating as an independent variable because the popularity of a president may affect how the media reports on a scandal. Our first model is designed to determine the effect of the current state of the economy on the incidence of a presidential scandal. In this model we include the misery index as the indicator of the economic conditions of the nation. Our second model includes the CSI to determine the impact that the prospective evaluation of the economy has on the timing of scandals. The CSI should be a strong determinant of the incidence of a presidential scandal because people's beliefs regarding the future state of the economy would dictate whether they watch the news for entertainment or information about the economy.

In both of these logit models, the beginning date of a presidential scandal is the first time the scandal is men-

5http://www.correlatesofwar.org/news/mid-data-set-v4-01-available 
tioned in a network evening news broadcast. This point in time clearly marks the beginning of a presidential scandal because a scandal is not simply an act of misconduct; it also involves the tarnishing of the reputation of the accused that follows the public proclamation of his alleged misdeeds. Without it being mentioned on network evening newscasts, we cannot be assured that the majority of the population is aware of the scandal. While people often obtain their news from other sources, network evening newscasts generally report on stories in which the entire nation is interested, which makes them a clear indicator of which news stories are captivating the nation at any given time. An indicator based on the New York Times would likely be highly correlated because the New York Times is a new leader, but we prefer to use a media source with less of an elite focus. The data used to determine the first time that a scandal was mentioned on an evening news broadcast was acquired from the Vanderbilt News Archives. ${ }^{6}$

\section{Findings}

We include two sets of models in our analysis. The first set of models illustrates the impact that scandals have on presidential approval. The second set of models attempts to predict the occurrence of scandals. Table 1 shows the political costs of scandals to the president by looking at the impact that scandals have on presidential approval ratings. Table 1 includes three models: the first uses the misery index, the second includes the CSI and the third includes both economic indicators. We were initially hesitant to include both variables because they are correlated at 0.826 which provides a strong indication that these variables are capturing the same concept and introduces the problem of multicollinearity into the models. Surprisingly, when both variables are included in the model (Model 3), both variables are statistically significant even with the high correlation between the variables. In each model we use Prais-Winsten regression models to correct for first order autocorrelation. ${ }^{7}$ The Durbin-Watson statistics indicate that the transformations were successful in controlling the problem. All three models have significant $F$ values $(10.17,11.69,12.3)$ and $\mathrm{R}^{2}$ of $0.09,0.12$, and 0.14 .

Table 1. Prais-Winsten regression predicting presidential approval.

\begin{tabular}{|c|c|c|c|c|c|c|}
\hline & \multicolumn{2}{|c|}{ Model 1} & \multicolumn{2}{|c|}{ Model 2} & \multicolumn{2}{|c|}{ Model 3} \\
\hline & $b$ & (S.E.) & $b$ & (S.E.) & $b$ & (S.E.) \\
\hline Scandal & -9.12 & $(1.92)^{* * *}$ & -9.02 & $(1.92)^{* * *}$ & -9.60 & $(1.88)^{* * *+}$ \\
\hline Misery Index & -1.03 & $(0.33)^{* * *}$ & & & -1.14 & $(0.39)^{* * * *}$ \\
\hline CSI & & & 0.26 & $(0.07)^{* * *}$ & 0.21 & $(0.07)^{* * * *}$ \\
\hline Honeymoon Period & 2.28 & $(0.93)^{* *}$ & 2.06 & $(1.06)^{*}$ & 1.92 & $(1.06)^{*}$ \\
\hline Divided Government & 4.00 & $(1.62)^{* *}$ & 2.92 & (1.89) & 3.09 & $(1.82)^{*}$ \\
\hline Korean War & -4.12 & (3.07) & & & & \\
\hline Vietnam War & 0.52 & $(2.78)$ & 0.50 & $(2.74)$ & -1.01 & $(2.62)$ \\
\hline Gulf War (1990-1991) & 0.70 & $(3.22)$ & -0.06 & $(3.25)$ & 0.70 & (3.23) \\
\hline Constant & 64.53 & $(3.97)^{* * *}$ & 32.86 & $(6.16)^{* * *}$ & 49.00 & $(8.53)^{* * *}$ \\
\hline Rho & 0.91 & & 0.90 & & 0.88 & \\
\hline Num. of Obs. & 624 & & 492 & & 492 & \\
\hline $\mathrm{F}$ & 10.17 & $* * *$ & 11.69 & $* * *$ & 12.3 & $* * *$ \\
\hline Adj. R2 & 0.09 & & 0.12 & & 0.14 & \\
\hline \multicolumn{7}{|l|}{ Durbin-Watson } \\
\hline Original & 0.26 & & 0.31 & & 0.30 & \\
\hline Transformed & 1.98 & & 2.04 & & 2.01 & \\
\hline
\end{tabular}

${ }^{*} p<0.1 ;{ }^{* *} p<0.05 ;{ }^{* * *} p<0.01$.

${ }^{6}$ https://dev-tvnews.library.vanderbilt.edu/

${ }^{7}$ We also ran models with lags of the dependent variable instead of a Prais-Winsten transformation. The statistical significance of all theoretical variables was consistent across models. 
There is nothing in this model that violates conventional wisdom. The impact of the economy is consistent across all three models. Whether the model includes a retrospective measure, such as the misery index, or the prospective measure, such as CSI, the results are consistent; a poor economy results in lower presidential approval ratings. This is consistent with a myriad of earlier findings that have demonstrated the strong relationship between economics and presidential approval. In each model the presence of a scandal has a very strong negative impact on presidential approval. According to the model, on average, a scandal will drop presidential approval ratings by almost 10 percentage points. The public's dislike for a president that they perceive to be dishonest was reflected in these results. Of the control variables, two are significant. The honeymoon period is significant in each of the three models. The honeymoon period has a small positive impact on presidential approval as expected. Divided government is significant in two of the three models and has a $p$. value of 0.12 in the third. Divided government improves the popularity of the president. This may be a result of higher expectations from a unified government or from the ability of the president to blame the other party controlling Congress during periods of divided government. Surprisingly, the wars included in the model are not significant. This may have been a result in how the wars were coded. The public's awareness and reaction to the conflict may change over time resulting in the insignificant findings. For example, Norpoth (1996) divides the Gulf War into three periods and finds that only the last period has a statistically significant impact on approval.

The models in Table 1 indicate that scandals adversely affect presidential approval ratings. The more interesting question is whether or not we can predict the occurrence of scandals. We believe that there is a non-random component in the timing of scandals, with the primary predictors of scandals being divided government and a strong economy. Table 2 presents three models that are once again divided by economic indicator. Unlike in Table 1, CSI is insignificant in Model 3. There is a very good chance this is due to the correlation between CSI and the misery index. Because of this we will focus on Models 1 and 2 rather than Model 3. We initially included dummy variables for each war that occurred during the time span of our study. The Korean War and the Gulf War perfectly predicted the absence of scandal and dropped out of the model during estimation, while Vietnam was negative as expected. This supports our argument that wars should greatly reduce the likelihood of scandals.

In all three models divided government has a significant impact on the likelihood of a scandal. In fact, the impact is so powerful it is almost a necessary condition for scandals. During periods of unified government partisan politics is likely to intervene to prevent the competition between Congress and the president from resulting in scandals. During periods of divided government there are no ties between the president and Congress to prevent Congress from attacking the president. In addition, divided government also makes it politically appealing to attack the president and focus on scandalous behavior. When we add economics into the equation we get a clear picture of the type of environment that will encourage scandals. In Model 1 the misery index has a negative relationship to the occurrence of scandals. This means that the worse the economy performs the less likely a

Table 2. Logit models predicting presidential scandals.

\begin{tabular}{|c|c|c|c|c|c|c|}
\hline & \multicolumn{2}{|c|}{ Model 1} & \multicolumn{2}{|c|}{ Model 2} & \multicolumn{2}{|c|}{ Model 3} \\
\hline & $b$ & (S.E.) & $b$ & (S.E.) & $b$ & (S.E.) \\
\hline Misery Index & -0.53 & $(0.07)^{* * *}$ & & & -1.01 & $(0.13)^{* * *}$ \\
\hline CSI & & & 0.14 & $(0.02)^{* * *}$ & 0.01 & $(0.02)$ \\
\hline Divided & 3.18 & $(0.44)^{* * *}$ & 1.76 & $(0.36)^{* * *}$ & 3.33 & $(0.49)^{* * *}$ \\
\hline Lag of Approval & -0.15 & $(0.02)^{* * *}$ & -0.11 & $(0.02)^{* * *}$ & -0.17 & $(0.02)^{* * * *}$ \\
\hline Honeymoon & 0.44 & $(0.55)$ & -0.33 & $(0.56)$ & -0.15 & $(0.66)$ \\
\hline Vietnam War & -1.89 & $(0.45)^{* * *}$ & -2.02 & $(0.46)^{* * *}$ & -3.54 & $(0.53)^{* * * *}$ \\
\hline Constant & 9.39 & $(1.32)^{* * * *}$ & -9.23 & $(1.21)^{* * * *}$ & 14.82 & $(2.97)^{* * * *}$ \\
\hline Num. of Obs. & 576 & & 483 & & 483 & \\
\hline$\chi^{2}$ & 215.64 & $* * *$ & 216.39 & $* * *$ & 322.37 & $* * *$ \\
\hline
\end{tabular}

${ }^{*} p<0.1 ;{ }^{* *} p<0.05 ;{ }^{* * *} p<0.01$.


scandal will occur. Figure 1 shows the predicted probability of a scandal from the lowest misery index included in the sample to the highest misery index included. Two sets of probabilities were calculated: the first with divided government and the second with unified government. When there is unified government the probability of a scandal never reaches higher than $15 \%$ even in the best economic times. During periods of divided government the likelihood of a scandal exceeds $50 \%$ with a misery index of $8.4 \%$. As the misery index falls and the economy performs better the likelihood of a scandal steadily increases to near $90 \%$ at the strongest economic period in our study.

Model 2 in Table 2 yields similar results to Model 1 . The only difference in the model is the inclusion of the CSI rather than the misery index. It should be noted that the CSI and misery index are coded in opposite directions. This means that a positive coefficient for the CSI variable is comparable to a negative coefficient for the misery index variable. The stronger the CSI the more likely a scandal will occur. The effect of divided government is not as powerful in this case as in Model 1, but divided government does significantly increase the likelihood of a scandal. Figure 2 shows the predicted probabilities. Once again we only see a high likelihood of scandals when there is a strong economy. Even the presence of divided government does not create a high likelihood of scandals when the economy is performing very poorly.

Two control variables were statistically significant. The impact of these variables on the predicted probability of a scandal can be seen in Table 3. The lag of the presidential approval rating had a negative effect on the inci-

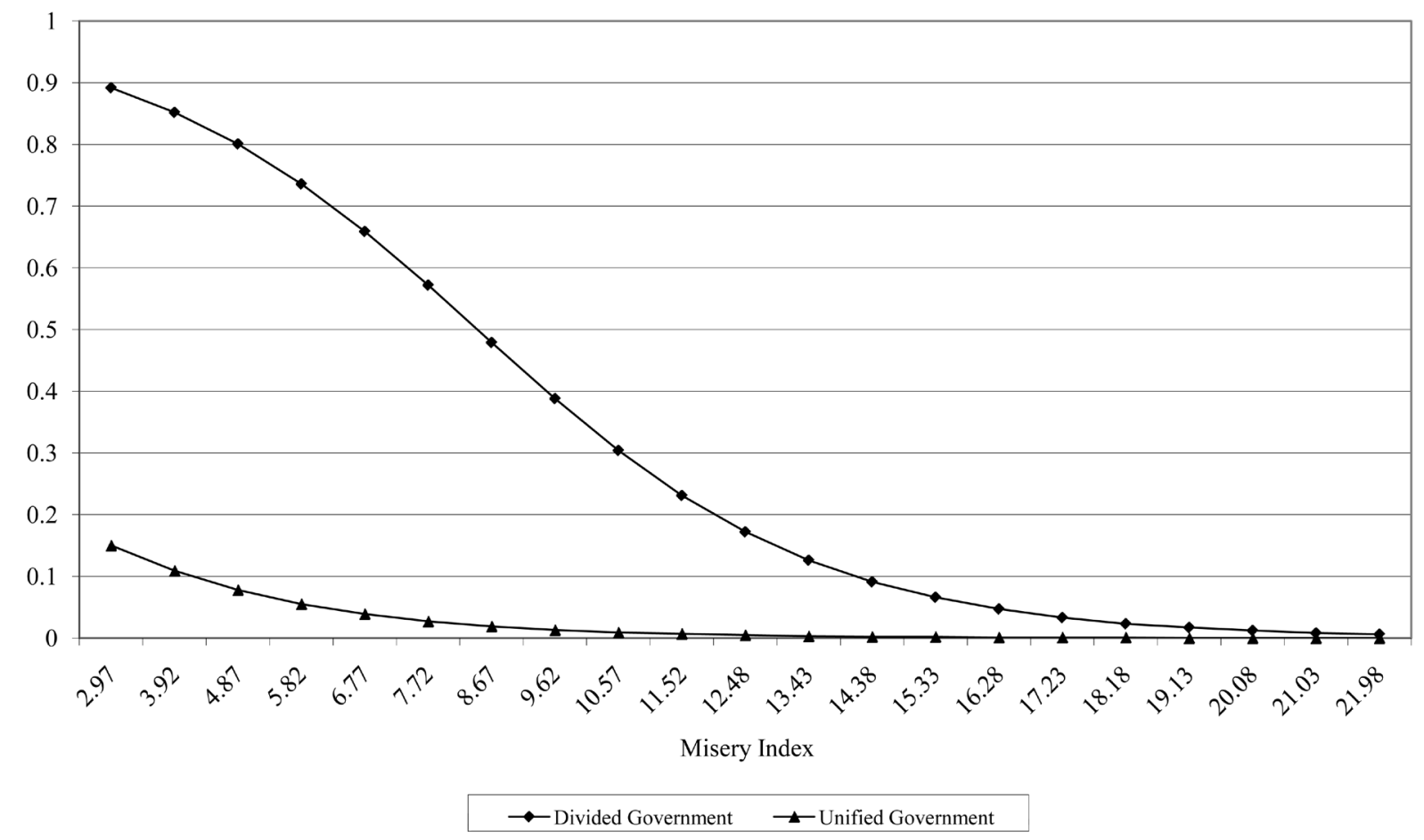

Figure 1. Probability of scandal by misery index.

Table 3. Predicted probabilities for control variables.

\begin{tabular}{ccc}
\hline & Model 1-Misery Index & Model 2-CSI \\
\hline Vietnam War & 0.14 & 0.08 \\
No War & 0.39 & 0.38 \\
Lag of Approval & & 0.15 \\
High & 0.16 & 0.38 \\
Mean & 0.39 & 0.68 \\
Low & 0.69 & \\
\hline
\end{tabular}




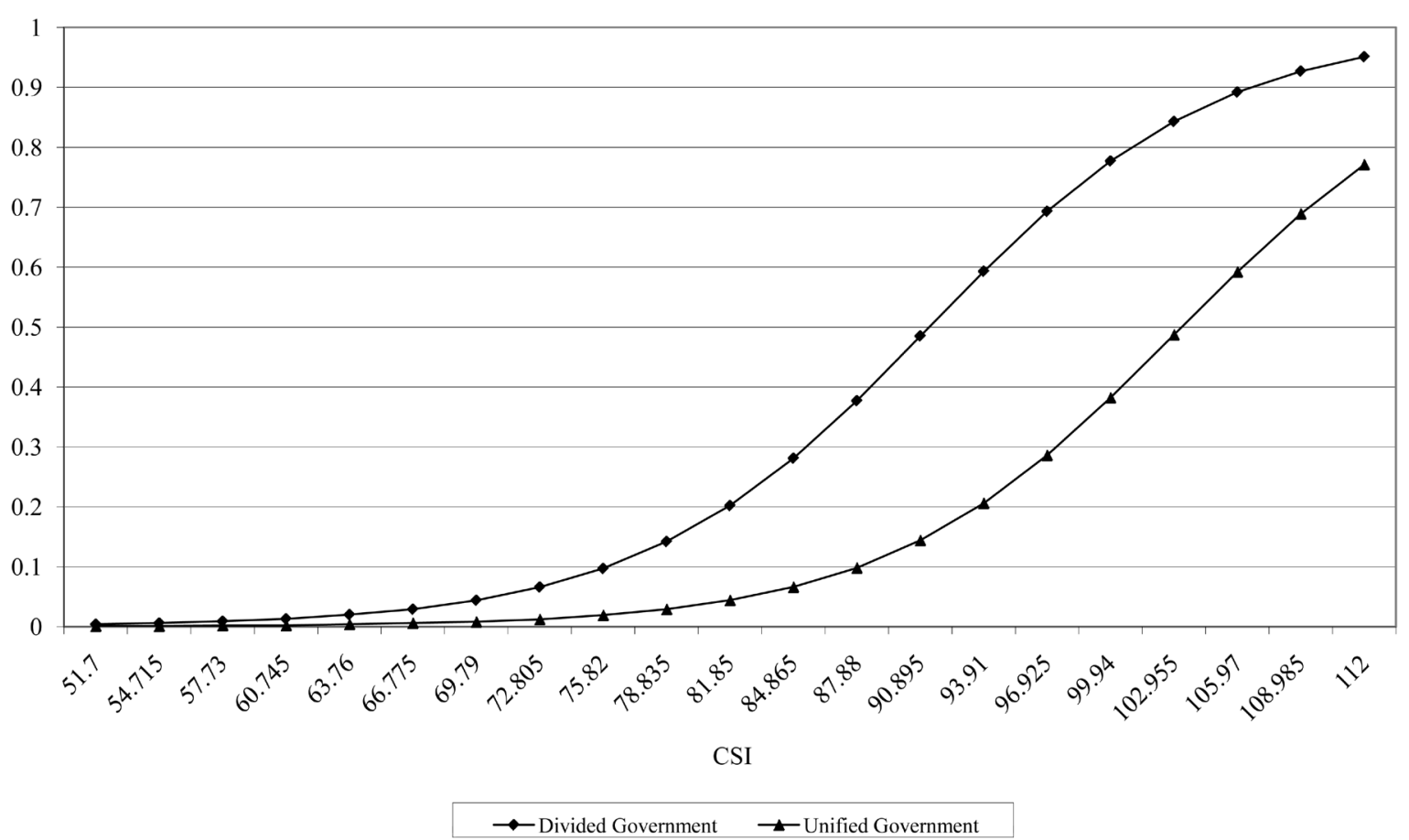

Figure 2. Probability of scandal by CSI.

dence of a presidential scandal in all three models. Extremely popular presidents are less likely to be attacked than an unpopular president. We used the lag of approval to make sure that the approval rating preceded the scandal. The probabilities in Table 3 are calculated with all other variables set at their mean or modal value. This means that the probabilities shown are for divided government. During periods of unified government the probability of scandal is much lower regardless of approval rating.

The Vietnam War had a statistically significant negative effect on the incidence of a presidential scandal in all three models. The Vietnam War reduced the probability of a scandal by at least $30 \%$ in each model. The public's interest in information about the ongoing war precluded the media from seeking out and reporting on presidential scandals during the Vietnam War. It should be noted that we cannot make generalizations about the impact of war on the occurrence of scandals since we only have one event to base our conclusions on. That being said there were no political scandals during Korea, Vietnam or Gulf War and there does not appear to be any scandals during the second Gulf War under George W. Bush.

The above results indicate that scandals are not entirely random events. Certain political environments make scandals more likely to occur. Divided government has the strongest impact. In some models, it was an almost necessary condition for a scandal to occur. This indicates that partisan politics is still more important than competition between institutions. It also appears that partisan conflict is as important to scandals as the act of wrongdoing itself. Economics is also a strong indicator of scandals with a strong economy providing a fertile environment for scandals to develop. A weak economy stifles scandals by most likely focusing the attention of politicians and the public on economic concerns. These findings provide the foundation for moving beyond treating scandals as random events and the motivation to more closely examine the political landscape from which scandals are born.

\section{Conclusion}

Throughout this analysis, we have examined the various factors that contribute to fluctuations in both the presidential approval rating and the incidence of presidential scandals. Supporting earlier findings, we illustrate that the incidence of scandals and poor economic conditions negatively impacted the approval rating of the president while the honeymoon period and divided government tend to improve approval ratings. People like presidents that are in office when economic conditions are favorable. Scandals greatly reduce approval ratings, which make 
them attractive weapons for political adversaries.

Presidential scandals do not appear to be completely random. Poor economic conditions and Vietnam greatly reduced the likelihood of a scandal. Apparently, when the state of the American economy is favorable and people stop worrying about their own job security, or the safety of their fellow citizens who are serving in combat, they follow coverage of presidential scandals. When the previously-mentioned conditions prevail within the United States, people often watch the news for entertainment purposes. The media responds to this preference by giving them coverage of presidential scandals, a subject which people find to be highly entertaining. These findings rest on the important assumption that there are always scandalous activities that can be exposed at any time. Some scholars would have trouble making this assumption because they prefer to see scandals as rare random events by a few corrupt individuals and not a regular component of the American political landscape. But as Mayhew (1991) points out, Congress is almost always investigating some aspect of the executive branch. In addition, we only need the perception of inappropriate behavior, not actual wrongdoing. The strongest argument for this assumption is in the models themselves. The models in Table 2 clearly indicate that there are political environments more likely to spawn scandals.

\section{References}

Abramowitz, A. I. (1985). Economic Conditions, Presidential Popularity, and Voting Behavior in Midterm Congressional Elections. The Journal of Politics, 47, 31-43. http://dx.doi.org/10.2307/2131064

Beck, N. (1991). Comparing Dynamic Specifications: The Case of Presidential Approval. In J. A. Stimson (Ed.), Political Analysis (Vol. 3, pp. 51-88.), Ann Arbor: University of Michigan Press. http://dx.doi.org/10.1093/pan/3.1.51

Brace, P., \& Hinckley, B. (1991). The Structure of Presidential Approval: Constraints Within and Across Presidencies. The Journal of Politics, 53, 993-1017. http://dx.doi.org/10.2307/2131864

Conley, R. S. (2003). The Presidency, Congress, and Divided Government: A Postwar Assessment. College Station: Texas A\&M University Press.

Fackler, T., \& Lin, T. (1995). Political Corruption and Presidential Election, 1929-1992. Journal of Politics, 57, $971-993$. http://dx.doi.org/10.2307/2960398

Gerhardt, M. J. (2000). The Impeachment and Acquittal of President William Jefferson Clinton. In J. Mark (Ed.), The Clinton Scandal and the Future of American Government (pp. 142-160). Washington DC: Georgetown University.

Greene, S. (2001). The Role of Character Assessments in Presidential Approval. American Politics Research, 29, $196-210$. http://dx.doi.org/10.1177/1532673X01029002004

Kagay, M. R. (1999). Presidential Address: Public Opinion and Polling during Presidential Scandal and Impeachment. Public Opinion Quarterly, 63, 449-463. http://dx.doi.org/10.1086/297734

Lanoue, D. J. (1994). Prospective and Retrospective Voting in Presidential-Year Elections. Political Research Quarterly, 47, 193-205. http://dx.doi.org/10.1177/106591299404700110

Lockerbie, B. (1992). Prospective Voting in Presidential Elections: 1956-1988. American Politics Quarterly, 20, 308-325. http://dx.doi.org/10.1177/1532673X9202000303

Maurer, P. J. (1999). Media Feeding Frenzies: Press Behavior during Two Clinton Scandals. Presidential Studies Quarterly, 29, 65-79. http://dx.doi.org/10.1111/1741-5705.00019

Mayhew, D. R. (1991). Divided We Govern: Party Control, Lawmaking, and Investigations, 1946-1990. New Haven: Yale University Press.

Nadeau, R., Niemi, R. G., Fan, D. P., \& Amato, T. (1999). Elite Economic Forecasts, Economic News, Mass Economic Judgements, and Presidential Approval. Journal of Politics, 61, 109-135. http://dx.doi.org/10.2307/2647777

Norpoth, H. (1996). Presidents and the Prospective Voter. The Journal of Politics, 58, 776-792. http://dx.doi.org/10.2307/2960444

Olson, K. W. (2003). Watergate: The Presidential Scandal That Shook America. Lawrence, KS: University Press of Kansas.

Parker, S. L. (1995). Toward an Understanding of "Rally” Effects: Public Opinion in the Persian Gulf War. Public Opinion Quarterly, 59, 526-546. http://dx.doi.org/10.1086/269492

Pfiffner, J. P. (1994). The Modern Presidency. New York: St. Martin’s Press.

Quirk, P. J. (2000). Scandal Time: The Clinton Impeachment and the Distraction of American Politics. In M. J. Rozell, \& C. Wilcox (Eds). The Clinton Scandal and the Future of American Government (pp. 119-141), Washington DC: Georgetown University Press. 
Renshon, S. A. (2002a). The Polls: The Public's Response to the Clinton Scandals, Part 1: Inconsistent Theories, Contradictory Evidence. Presidential Studies Quarterly, 32, 169-184.

Renshon, S. A. (2002b). The Polls: The Public's Response to the Clinton Scandals, Part 2: Diverse Explanations, Clearer Consequences. Presidential Studies Quarterly, 32, 412-427. http://dx.doi.org/10.1111/j.0360-4918.2002.00228.x

Sabato, L. J. (1991). Feeding Frenzy: How Attack Journalism Has Transformed American Politics. New York: Free Press.

Schultz, J. D. (2000). Presidential Scandals. Washington DC: CQ Press.

Sinclair, B. (2000). Hostile Partners: The President, Congress, and Lawmaking in the Partisan 1990s. In J. R. Bond, \& R. Fleisher (Eds.), Polarized Politics (pp. 144-145). Washington DC: CQ Press.

Williams, R. (2000). Political Scandals in the USA. Chicago, IL: Fitzroy Dearborn Publishers. 